\title{
Meta
}

Journal des traducteurs

Translators' Journal

\section{BELLOS, DAVID (2012) : Le poisson et le bananier. Une histoire fabuleuse de la traduction. Paris : Flammarion, 394 p.}

\section{MariaCristina Pedrazzini}

Volume 58, numéro 1, avril 2013

URI : https://id.erudit.org/iderudit/1023820ar

DOI : https://doi.org/10.7202/1023820ar

Aller au sommaire du numéro

Éditeur(s)

Les Presses de l’Université de Montréal

ISSN

0026-0452 (imprimé)

1492-1421 (numérique)

Découvrir la revue

Citer ce compte rendu

Pedrazzini, M. (2013). Compte rendu de [BELlos, DAviD (2012) : Le poisson et le bananier. Une histoire fabuleuse de la traduction. Paris : Flammarion, 394 p.]

Meta, 58(1), 251-252. https://doi.org/10.7202/1023820ar d'utilisation que vous pouvez consulter en ligne.

https://apropos.erudit.org/fr/usagers/politique-dutilisation/ 
Bellos, David (2012): Le poisson et le bananier. Une histoire fabuleuse de la traduction. Paris: Flammarion, $394 \mathrm{p}$.

Ce texte est la traduction par Daniel Loayza, avec la collaboration de l'auteur David Bellos, de l'anglais Is That a Fish in Your Ear? Translation and the Meaning of Everything, Penguin Books 2011. David Bellos est professeur de littérature française et comparée aux États-Unis (Princeton University), dirige un cursus de traduction et de communication interculturelle et est traducteur lui-même.

Selon les affirmations de l'auteur,

[c]e livre existe en anglais en deux versions distinctes - l'une, destinée au Royaume-Uni et en vente également au Canada, en Australie et en Inde; l'autre, conçue pour les lecteurs des États-Unis. Il n'y a pas un seul paragraphe de l'une qui soit identique en tous points au paragraphe correspondant de l'autre. [...] C'est pourquoi la version française que voici - malgré les coupes et les ajouts, les aménagements et les substitutions que le traducteur a introduites [sic] ou que l'auteur a inventées [sic] - est tout aussi authentique (et peut-être davantage) que son "original» décidément hypothétique. (p. 206-207)

Ce volume constitue donc un ouvrage original à part entière, avec son prologue (p. 11-13), trente-trois chapitres, des notes (p. 361-376), un index (p. 377-390) et des Avertissements et remerciements (p. 391-392) qui lui appartiennent en propre.

Sa couverture arbore, à gauche, le titre $L e$ poisson et le bananier "casé» à l'intérieur d'un être hybride associant la couleur de la banane à des nageoires et à une queue de poisson; et à droite, le sous-titre explicatif Une histoire fabuleuse de la traduction. Le titre ne dévoile ses mystères qu'aux pages 287 et 187 respectivement. Le poisson jaune évoque la "prothèse auditive [...] Poisson Babel» (p. 287) - qui permettrait de comprendre toutes les langues - inventée par l'humoriste anglais Douglas Adams dans The Hitchhiker's Guide to the Galaxy (1979) - Guide du voyageur galactique (1982). Le bananier, quant à lui, a fourni l'équivalent culturel du figuier dans la traduction malaise de l'évangile selon Matthieu, ce qui a permis à l'auteur d'intituler son quinzième chapitre Les bananes de Saint Matthieu. Traduction amont et traduction aval (p. 181-195). Le rapprochement des bananes et de Saint Matthieu peut paraître impertinent, mais la deuxième partie du titre rappelle que le propos du chapitre est sérieux.

Quel est le but d'un livre qui se présente comme Une histoire fabuleuse de la traduction? À part la modestie de l'article indéfini - nulle œuvre ne prétendant à l'unicité - le choix de l'adjectif «fabuleuse» indique la volonté de l'auteur de conjuguer l'érudition - l'histoire de la traduction - avec l'agilité et l'enjouement de l'anecdote. C'est ce que découvre le lecteur potentiel, déjà intrigué par le titre de l'ouvrage ou par ceux de certains chapitres, tels que le chapitre 14 (Combien de mots pour dire «café»? p. 171-180), le chapitre 24 (Un Poisson Babel dans votre oreille. La brève histoire de l'interprétation simultanée p. 277-290) ou le chapitre 30 (Tirez sur le traducteur! p. 337-340). Comme le lecteur pourra le voir dès le début de sa lecture, l'auteur l'implique dans une sorte de dialogue en répondant aux questions que tout un chacun pourrait se poser: 1. Qu'est-ce qu'une traduction? (p. 15-17), 2. Peut-on éviter la traduction? (p. 19-31), 3. Au fait, pourquoi «traduction»? (p. 33-44).

Certes, le traductologue y retrouvera des notions qu'il possède depuis longtemps - L1 et L2, méthodes de traduction, équivalences, transferts, etc. - , mais sous un jour différent, et complétées à l'aide de statistiques et de données récentes (cf. par exemple, le chapitre 19 Flux globaux. Centre et périphérie dans la traduction d'ouvrages (p. 219-232)

Le lecteur non-spécialiste, en revanche, découvrira un monde dont il n'a jamais soupçonné la complexité, voire l'existence. Il s'engagera alors dans un voyage d'exploration au cours duquel il rencontrera la pierre de Rosette et les serments de Strasbourg, il affrontera quelques étymologies - de la traduction elle-même comme du divorce -, des mythes anciens et modernes - de Babel, de la traduction littérale et d'Avatar -, les préjugés sur les langues et sur leur prétendu caractère intraduisible tout aussi bien que les enjeux linguistiques de la mondialisation et de la globalité.

Peut-être sourira-t-il de la «vieille histoire de la centaine de nuances de la neige en esquimau» (p. 176) aussi bien que de l'illusion nominale, ou bien il s'interrogera sur les conséquences de l'approche saussurienne du langage car « $[\mathrm{t}]$ out au long du $\mathrm{xx}^{\mathrm{e}}$ siècle, la théorie saussurienne du signe a justifié le peu d'intérêt porté à la traduction et aux perspectives qu'elle offre pour comprendre l'usage effectif que l'on fait des langues» (p. 236). Il découvrira, non sans admiration, que «Antanas Smetona, qui fut le dernier président de la Lituanie avant l'invasion des troupes soviétiques puis nazies en 1941, recourut au latin pour lancer (sans succès) son dernier appel à l'aide aux Alliés. » (p. 27).

$\mathrm{Au}$ fur et à mesure qu'il avance dans son voyage, notre lecteur non-spécialiste retrouvera dans sa mémoire des traces de ses lectures qu'il pourra enrichir et compléter. À moins d'avoir fait des études bibliques ou traductologiques poussées, sans doute ne saura-t-il dire quel rôle a joué saint Jérôme dans la traduction de la Bible en latin. S'il 
connaissait l'existence des esclaves dans l'antiquité, il ne s'est jamais attardé sur leur rôle d'interprètes chez les Ottomans ni sur le fait que Le Livre de Marco Polo fut «très probablement une traduction improvisée» (p. 213) de Rustichello de Pise, qui se trouvait être dans la même cellule que Marco Polo, ou que l'histoire d'Ossian et Le Château d'Otrante de Horace Walpole n'étaient que des pseudo-traductions dont il fallut avouer qu'elles constituaient une supercherie. Notre lecteur se doute que c'est au Tribunal militaire international de Nuremberg que l'on doit la réflexion sur la nécessité et sur les difficultés de la traduction simultanée dans les organismes supranationaux de l'époque et futurs - comme l'UE ou l'ONU. Encore fallait-il le lui rappeler.

Le projet était de taille à décourager bien des spécialistes: les risques de naïvetés et de redites étaient réels, cependant David Bellos a relevé le défi et, grâce à sa longue expérience traductologique et pédagogique, il a réussi dans son entreprise.

MariaCristina Pedrazzini Université Catholique de Milan, Italie

Robinson, Douglas (2011): Translation and the Problem of Sway. Amsterdam/Philadelphia: John Benjamins Publishing Company, 227 p.

As translation theories have evolved to integrate cultural elements over the past decades, the concept of faithfulness to the original or correctness inevitably ceased to be the dominant evaluative standards of particular translation products. The production and reception of translation are increasingly seen as a result of complex governing powers exerted by various aspects of cultural contexts. Those governing powers or pressures have become the focus of present day translation related studies. Among the different works theorizing those pressures, Descriptive Translation Studies are quite successful in describing the pressures driven by the literary norms of target culture and the professional agents, which can be seen as the characterizing the socioeconomic approach. Other theories place more emphasis on describing habitualized interpretation of certain translated products, such as Venuti's discussions on the concept of "interpretant" and Mona Baker's discussions about "narrativity." Translation and the Problem of Sway, authored by Douglas Robinson, makes a further contribution to the effort of theorizing those cultural formed habits and psychological trends along the lines of Venuti and Baker's work, but what makes his work innovative and contributory is the integration of the study of normative and non-normative sways using his own conceptual framework - somatic theory. This book consists of six chapters.

In Chapter 1, Introduction, Translation and Sway (pp. 1-15), the author suggests that "sway" which influences translator's work is defined too narrowly. The translation norms theorized by Toury are merely the "positive" versions of translational sways, which exclude explicit rules and fully subjective idiosyncrasy. Venuti's work on interpretant and Baker's work in narrativity also treat what sways the translator as "bias," which apparently carries a negative meaning. The author suggests, alternatively, to subsume the norms and values we hold most dear and the bias under the same category - "sway." To put the sway in Robinson' words, it is "almost a group dynamic, not typically something that happens inside individual nervous system (p. 9)," and those "sways" that weigh upon the translators' work are the focus of Robinson's book.

In Chapter 2, Lawrence Venuti on the Interpretant (pp. 17-39), the author introduces Venuti's concept of the interpretant and points out that the semiotic terms used by Venuti in this definition are largely depersonalized tend to reduce human creativity to a robotic sense, which is the staple viewpoint of many theorists like Martindale. The author introduces his somatic model of human interaction both to give Venuti's theory more complexity and to refute Martindale's accusation.

In Chapter 3, The Case of Alex. Matson (pp. 41-111), the author conducts a long case study of a single translator, Alex Matson (1888-1972), who spent his childhood in England and adulthood in his native Finland. The author analyses Matson's translations into Finnish of James Joyce's Portrait of the Artist as a Young Man and William Faulkner's Wild Palms and As I Lay Dying, and his translations into English of Aleksis Kivi's 1870 novel Seven Brothers and several works by Aino Kallas and F. E. Sillanpää with the objective of testing Venuti's "formal" interpretant. The case study finds that Matson's awkward English cannot be attributed to a foreignizing attention to the original. It also shows that Venuti's formal interpretant is not valid enough to account for the complexity of translation phenomenon. The author suggests that there are rhetorical interpretants guiding our interactions with other people; that rhetorical interpretants might be divided into logical interpretants (governing structure), pathetic interpretants (governing affective interaction), and ethical interpretants (governing the perception of character); and that Venuti's two types of interpretant, the formal and the thematic, should be seen as subcategories of the logical interpretant. 